\title{
Moderate-to-severe ischemic conditions increase activity and phosphorylation of the cerebral microvascular endothelial cell $\mathrm{Na}+\mathrm{K}+-\mathrm{Cl}-$ cotransporter
}

Shahin Foroutan, Julien Brillault, Biff Forbush and Martha E. O'Donnell

Am J Physiol Cell Physiol 289:1492-1501, 2005. First published Aug 3, 2005;

doi:10.1152/ajpcell.00257.2005

You might find this additional information useful...

This article cites 39 articles, 19 of which you can access free at:

http://ajpcell.physiology.org/cgi/content/full/289/6/C1492\#BIBL

This article has been cited by 2 other HighWire hosted articles:

Physiology and pathophysiology of $\mathrm{Na}+\mathrm{H}+$ exchange and $\mathrm{Na}+-\mathrm{K}+-2 \mathrm{Cl}-$ cotransport in the heart, brain, and blood

S. F. Pedersen, M. E. O'Donnell, S. E. Anderson and P. M. Cala

Am J Physiol Regulatory Integrative Comp Physiol, July 1, 2006; 291 (1): R1-R25.

[Abstract] [Full Text] [PDF]

Can a broken barrier be repaired?

P. A. Fraser

J. Physiol., June 1, 2006; 573 (2): 287-287.

[Full Text] [PDF]

Updated information and services including high-resolution figures, can be found at:

http://ajpcell.physiology.org/cgi/content/full/289/6/C1492

Additional material and information about AJP - Cell Physiology can be found at: http://www.the-aps.org/publications/ajpcell

This information is current as of March 22, 2007. 


\title{
Moderate-to-severe ischemic conditions increase activity and phosphorylation of the cerebral microvascular endothelial cell $\mathrm{Na}^{+}-\mathrm{K}^{+}-\mathrm{Cl}^{-}$cotransporter
}

\author{
Shahin Foroutan, ${ }^{\mathbf{1}}$ Julien Brillault, ${ }^{\mathbf{1}}$ Biff Forbush, ${ }^{\mathbf{2}}$ and Martha E. O'Donnell ${ }^{\mathbf{1}}$ \\ ${ }^{1}$ Department of Physiology and Membrane Biology, School of Medicine, University of California, Davis, California; \\ and ${ }^{2}$ Department of Cellular and Molecular Physiology, Yale University School of Medicine, New Haven, Connecticut
}

Submitted 31 May 2005; accepted in final form 30 July 2005

Foroutan, Shahin, Julien Brillault, Biff Forbush, and Martha E. O'Donnell. Moderate-to-severe ischemic conditions increase activity and phosphorylation of the cerebral microvascular endothelial cell $\mathrm{Na}^{+}-\mathrm{K}^{+}$$\mathrm{Cl}^{-}$cotransporter. Am J Physiol Cell Physiol 289: C1492-C1501, 2005. First published August 3, 2005; doi:10.1152/ajpcell.00257.2005.-Brain edema that forms during the early stages of stroke involves increased transport of $\mathrm{Na}^{+}$and $\mathrm{Cl}^{-}$across an intact blood-brain barrier (BBB). Our previous studies have shown that a luminal BBB Na+$-\mathrm{K}^{+}-\mathrm{Cl}^{-}$cotransporter is stimulated by conditions present during ischemia and that inhibition of the cotransporter by intravenous bumetanide greatly reduces edema formation in the rat middle cerebral artery occlusion model of stroke. The present study focused on investigating the effects of hypoxia, which develops rapidly in the brain during ischemia, on the activity and expression of the $\mathrm{BBB} \mathrm{Na}{ }^{+}-\mathrm{K}^{+}-\mathrm{Cl}^{-}$cotransporter, as well as on $\mathrm{Na}^{+}-\mathrm{K}^{+}$-ATPase activity, cell ATP content, and intracellular volume. Cerebral microvascular endothelial cells (CMECs) were assessed for $\mathrm{Na}^{+}-\mathrm{K}^{+}-\mathrm{Cl}^{-}$cotransporter and $\mathrm{Na}^{+}-\mathrm{K}^{+}$-ATPase activities as bumetanide-sensitive and ouabain-sensitive ${ }^{86} \mathrm{Rb}$ influxes, respectively. ATP content was assessed by luciferase assay and intracellular volume by $\left[{ }^{3} \mathrm{H}\right]-3-\mathrm{O}$-methyl-D-glucose and $\left[{ }^{14} \mathrm{C}\right]$-sucrose equilibration. We found that 30-min exposure of CMECs to hypoxia ranging from $7.5 \%$ to $0.5 \% \mathrm{O}_{2}$ (vs. $19 \%$ normoxic $\mathrm{O}_{2}$ ) significantly increased cotransporter activity as did $7.5 \%$ or $2 \% \mathrm{O}_{2}$ for up to $2 \mathrm{~h}$. This was not associated with reduction in $\mathrm{Na}^{+}-\mathrm{K}^{+}$-ATPase activity or ATP content. CMEC intracellular volume increased only after 4 to $5 \mathrm{~h}$ of hypoxia. Furthermore, glucose and pyruvate deprivation increased cotransporter activity under both normoxic and hypoxic conditions. Finally, we found that hypoxia increased phosphorylation but not abundance of the cotransporter protein. These findings support the hypothesis that hypoxia stimulation of the $\mathrm{BBB} \mathrm{Na}{ }^{+}-\mathrm{K}^{+}-\mathrm{Cl}^{-}$cotransporter contributes to ischemia-induced brain edema formation.

edema; blood-brain barrier; bumetanide; cell volume

DURING STROKE, the early stages of brain edema formation involve net uptake of ions and water from blood into brain across an intact blood-brain barrier (BBB), with breakdown of the barrier not occurring until $4-6 \mathrm{~h}$ after the onset of ischemia $(24,31,42)$. In the healthy normoxic brain, BBB endothelial cells secrete up to $30 \%$ of brain interstitial fluid as they transport $\mathrm{Na}^{+}$and $\mathrm{Cl}^{-}$across the barrier $(9,22)$. Ischemia induces $\mathrm{BBB}$ hypersecretion of $\mathrm{Na}^{+}$and $\mathrm{Cl}^{-}$into the brain, promoting edema formation $(24,31,42)$. At the same time, cytotoxic edema develops as astrocytes take up $\mathrm{Na}^{+}, \mathrm{Cl}^{-}$, and water from the brain interstitial space and rapidly swell $(7,18$, 23). Although the ion transport pathways responsible for BBB hypersecretion have not been well understood, previous studies $(4-6,19,42)$ have provided evidence that the process occurs

Address for reprint requests and other correspondence: M. E. O'Donnell, Dept. of Physiology and Membrane Biology, School of Medicine, Univ. of California, One Shields Ave., Davis, CA 95616 (e-mail: meodonnell @ucdavis.edu). via a luminal $\mathrm{Na}^{+}$transporter working in tandem with abluminal $\mathrm{Na}^{+}-\mathrm{K}^{+}$-ATPase and $\mathrm{Cl}^{-}$efflux pathways.

Our previous studies have provided immunoelectron micrographic evidence that the $\mathrm{Na}^{+}-\mathrm{K}^{+}-\mathrm{Cl}^{-}$cotransporter is located predominantly in the luminal membrane of $\mathrm{BBB}$ endothelial cells in situ (34), consistent with the hypothesis that the cotransporter serves as the luminal $\mathrm{Na}^{+}$and $\mathrm{Cl}^{-}$influx pathway during ischemia-induced $\mathrm{BBB} \mathrm{Na}{ }^{+}$and $\mathrm{Cl}^{-}$secretion and subsequent edema formation. In further support of this hypothesis, we have also demonstrated that intravenous administration of the $\mathrm{Na}^{+}-\mathrm{K}^{+}-\mathrm{Cl}^{-}$cotransport inhibitor bumetanide greatly reduces edema formation that occurs in the early stages of stroke before BBB breakdown (34). If the $\mathrm{Na}^{+}-\mathrm{K}^{+}-\mathrm{Cl}^{-}$ cotransporter is a major contributor to edema formation in stroke, then activity of the cotransporter should be stimulated by conditions present during cerebral ischemia. In a recent study (37), we found that arginine vasopressin, which is released centrally during stroke, and which has been shown to induce edema formation, is a potent and rapid stimulator of the cerebral microvascular endothelial cell (CMEC) $\mathrm{Na}^{+}-\mathrm{K}^{+}-\mathrm{Cl}^{-}$ cotransporter. In the present study, we turned our attention to examining the effects of hypoxia on the CMEC Na${ }^{+}-\mathrm{K}^{+}-\mathrm{Cl}^{-}$ cotransporter. Hypoxia, which develops rapidly during stroke due to the low $\mathrm{O}_{2}$ store in the brain, is a prominent factor present during ischemia. However, little is known about how it affects BBB ion transporters. Previous studies $(20,21)$ have shown that inducing chemical hypoxia with oligomycin causes an increase in $\mathrm{CMEC} \mathrm{Na}^{+}-\mathrm{K}^{+}-\mathrm{Cl}^{-}$cotransporter activity and that a 24-h exposure to true hypoxia can also stimulate the cotransporter. However, it is not known whether true hypoxia stimulates the cotransporter in a manner consistent with the ischemia-induced edema formation that occurs during stroke. If hypoxia stimulation of the $\mathrm{Na}^{+}-\mathrm{K}^{+}-\mathrm{Cl}^{-}$cotransporter contributes to edema formation, we should see that hypoxia levels typically found in a focal ischemic area stimulate the cotransporter and that this occurs within the first hour of ischemia. Thus, in the present study, we tested the effects of hypoxia at varying levels and exposure times on activity of the CMEC $\mathrm{Na}^{+}-\mathrm{K}^{+}-\mathrm{Cl}^{-}$cotransporter. Because our hypothesis predicts that hypoxia increases cotransporter activity in a manner that supports secretion of $\mathrm{Na}^{+}$and $\mathrm{Cl}^{-}$across the barrier in conjunction with abluminal $\mathrm{Na}^{+}-\mathrm{K}^{+}$-ATPase activity, in this study, we also evaluated the effects of hypoxia on activity of the $\mathrm{Na}^{+}-\mathrm{K}^{+}$-ATPase. In addition, we tested the effects of hypoxic conditions found to stimulate cotransporter activity on ATP content and intracellular volume of the cells. Finally, as

\footnotetext{
The costs of publication of this article were defrayed in part by the payment of page charges. The article must therefore be hereby marked "advertisement" in accordance with 18 U.S.C. Section 1734 solely to indicate this fact.
} 
an initial investigation of mechanisms involved in hypoxiastimulated $\mathrm{Na}^{+}-\mathrm{K}^{+}-\mathrm{Cl}^{-}$cotransporter activity, we determined whether hypoxia alters the expression and/or phosphorylation of the CMEC $\mathrm{Na}^{+}-\mathrm{K}^{+}-\mathrm{Cl}^{-}$cotransporter protein.

We report herein that the $\mathrm{CMEC} \mathrm{Na}{ }^{+}-\mathrm{K}^{+}-\mathrm{Cl}^{-}$cotransporter is stimulated within $30 \mathrm{~min}$ by hypoxia levels ranging from $39 \%$ to $2.6 \%$ of normoxia but that neither ATP content nor $\mathrm{Na}^{+}-\mathrm{K}^{+}$-ATPase activity is significantly reduced under the same conditions. In addition, we provide evidence that exposure of the cells to hypoxia does not produce a significant increase in cell volume until 4 to $5 \mathrm{~h}$ of exposure, which is consistent with cotransporter stimulation supporting secretion during early phases of stroke, rather than a simple swelling of the BBB cells. Finally, we report that hypoxia conditions that stimulate CMEC cotransporter activity also increase phosphorylation of the cotransporter protein.

\section{MATERIALS AND METHODS}

Cell culture. Bovine CMECs were grown on collagen- and fibronectin-coated multiwell plates. Culture medium used was Dulbecco's modified Eagle's medium (DMEM) containing $5.6 \mathrm{mM}$ D-glucose, $1 \mathrm{mM} \mathrm{Na}^{+}$-pyruvate, and supplemented with $2 \mathrm{mM} \mathrm{L}$ glutamine, $50 \mu \mathrm{g} / \mathrm{ml}$ gentamicin, $1 \mathrm{ng} / \mathrm{ml}$ basic fibroblast growth factor, 5\% horse serum, and 5\% calf serum. Cells were refed with a 50:50 (vol/vol) mixture of fresh DMEM containing 10\% fetal bovine serum (FBS) and astrocyte-conditioned medium 2 days before each experiment. Astrocyte-conditioned medium was prepared by exposing primary rat astrocytes to DMEM/10\% FBS for $72 \mathrm{~h}$ and then filtering the medium through a $0.2-\mu \mathrm{m}$-thick membrane. CMECs used for this study were obtained from Cell Systems (Kirkland, WA). Astrocytes were isolated and cultured as described by our previous studies $(38,43)$.

$K^{+}$influx assays. $\mathrm{Na}^{+}-\mathrm{K}^{+}-\mathrm{Cl}^{-}$cotransporter activity of CMECs was assessed as ouabain-insensitive, bumetanide-sensitive ${ }^{86} \mathrm{Rb}$ influx, and $\mathrm{Na}^{+}-\mathrm{K}^{+}$-ATPase activity was measured as bumetanideinsensitive, ouabain-sensitive ${ }^{86} \mathrm{Rb}$ influx as described by us previously $(37,38)$. For the present studies, confluent monolayers of CMEC grown on 96-well plates were placed in a hypoxia chamber (COY Laboratory Products, Grass Lake, MI) preset to $37^{\circ} \mathrm{C}, 5 \% \mathrm{CO}_{2}$, and the desired oxygen level, ranging from $19 \% \mathrm{O}_{2}$ to $0.5 \% \mathrm{O}_{2} . \mathrm{O}_{2}$ levels were lowered by addition of nitrogen gas to the chamber (via $\mathrm{O}_{2}$ sensor/regulator). Verification of $\mathrm{O}_{2}$ levels in the treatment media (after equilibration with the chamber atmosphere) was done using a Corning dissolved oxygen sensor with Checkmate II meter (Corning, NY). In these studies, normoxic $\mathrm{O}_{2}$ (control) was $19 \%$, the same $\mathrm{O}_{2}$ level present in the tissue culture incubator used to grow and maintain the cells before the experiment (inclusion of $5 \% \mathrm{CO}_{2}$ in the incubator and hypoxia chamber environments reduces the $\mathrm{O}_{2}$ level to $19 \%$ from the ambient level of 20\%). It should be noted that previous studies $(30,32)$ have shown $\mathrm{O}_{2}$ to be soluble in plastic such that plastic tissue culture wells can provide a source of $\mathrm{O}_{2}$ in anoxia and hypoxia experiments. In a few experiments, we continuously monitored $\mathrm{O}_{2}$ content of $7.5 \%$ and $2 \%$ media after introduction into a tissue culture well. We found that for $7.5 \% \mathrm{O}_{2}$ media placed in wells with cells (as in our experiments), the $\mathrm{O}_{2}$ level increased to $8.8 \%$ by $3 \mathrm{~min}$ and fell to $8.1 \%$ by $30 \mathrm{~min}$. For $2 \% \mathrm{O}_{2}$ media placed in wells with cells, the $\mathrm{O}_{2}$ level increased to $3.2 \% \mathrm{O}_{2}$ at $1 \mathrm{~min}$ and fell to $2.5 \% \mathrm{O}_{2}$ by $30 \mathrm{~min}$. Thus the actual $\mathrm{O}_{2}$ level experienced by the cells in our studies is likely to be transiently somewhat higher (by $\sim 1 \%$ ) than the preequilibrated $\mathrm{O}_{2}$ level of the assay media added to the wells. If we placed $7.5 \%$ or $2 \% \mathrm{O}_{2}$ media in wells preexposed to normoxic media alone (i.e., no cells), the $\mathrm{O}_{2}$ levels increased transiently to $10.1 \%$ and $4.2 \%$, respectively, before returning to the target $\mathrm{O}_{2}$ levels. However, it should be noted that a previous study has shown $\mathrm{O}_{2}$ release into anoxic media to be markedly decreased in wells previously used to culture cells (and then cells removed before the addition of anoxic media) compared with cells never exposed to media or cells (30). While it is difficult to create a precise step change from normoxia to hypoxia, our $\mathrm{O}_{2}$ measurements indicate that by $30 \mathrm{~min}$, the drop to the intended $7.5 \%$ and $2 \% \mathrm{O}_{2}$ levels to which the cells are exposed is $93 \%$ to $97 \%$ complete.

For $\mathrm{K}^{+}$influx assays, immediately upon placing CMECs in the hypoxia chamber, growth medium was replaced with the appropriate pretreatment/assay medium preequilibrated to the desired $\mathrm{O}_{2}$ level. The pretreatment/assay medium used in the $\mathrm{K}^{+}$flux assays was DMEM containing $10 \mathrm{mM}$ HEPES (HEPES DMEM). This medium also contained (in mM) $5.6 \mathrm{D}$-glucose and $1.0 \mathrm{Na}^{+}$-pyruvate, 156 $\mathrm{Na}^{+}, 119 \mathrm{Cl}^{-}, 5.3 \mathrm{~K}^{+}, 1.8 \mathrm{Ca}^{2+}, 44.1 \mathrm{HCO}_{3}^{-}, 0.91 \mathrm{H}_{2} \mathrm{PO}_{4}, 0.81$ $\mathrm{Mg}^{2+}$, and $0.81 \mathrm{SO}_{4}^{2-}$. In some experiments, glucose and/or pyruvate were omitted from the pretreatment/assay media. CMECs were exposed to the pretreatment media with the desired $\mathrm{O}_{2}$ level for varying times (up to $240 \mathrm{~min}$ ), with bumetanide and/or ouabain (final concentrations of 10 and $100 \mu \mathrm{M}$, respectively) present during the last $7 \mathrm{~min}$. Finally, $\mathrm{K}^{+}$influx was assayed by addition of ${ }^{86} \mathrm{Rb}(1 \mu \mathrm{Ci} / \mathrm{ml})$ to the pretreatment/assay media for a subsequent 7-min incubation. The assay was terminated by rapidly washing monolayers with ice-cold isotonic $\mathrm{MgCl}_{2}$. Cell-associated radioactivity was determined by liquid scintillation counting after extraction in $0.2 \%$ SDS. ${ }^{86} \mathrm{Rb}$ uptake by the cells, which remains linear throughout the assay period, was calculated as the slope of an uptake versus time plot as described previously (35). The total protein in each well was measured by bicinchoninic acid (BCA) assay (Pierce, Rockford, IL). $\mathrm{K}^{+}$influxes mediated by the $\mathrm{Na}^{+}-\mathrm{K}^{+}-\mathrm{Cl}^{-}$cotransporter and $\mathrm{Na}^{+}-\mathrm{K}^{+}$-ATPase were expressed as micromoles of $\mathrm{K}^{+}$per gram of protein per minute. By these methods, total $\mathrm{K}^{+}$influx (no bumetanide, no ouabain) under control conditions was $21.39 \pm 1.04 \mu \mathrm{mol} \mathrm{K}{ }^{+} \cdot \mathrm{g}$ protein ${ }^{-1} \cdot \mathrm{min}^{-1}$ (means $\pm \mathrm{SE}, 17$ experiments). Bumetanide-sensitive $\mathrm{K}^{+}$influx was $11.71 \pm 0.95$ and $10.60 \pm 0.66 \mu \mathrm{mol} \mathrm{K}+\mathrm{g}$ protein ${ }^{-1} \cdot \min ^{-1}$ when measured in the presence and absence of ouabain, respectively. Ouabain-sensitive $\mathrm{K}^{+}$influx was $8.60 \pm 0.60$ and $6.99 \pm 0.92 \mu \mathrm{mol}$ $\mathrm{K}^{+} \cdot \mathrm{g}$ protein ${ }^{-1} \cdot \mathrm{min}^{-1}$ when measured in the presence and absence of bumetanide, respectively. The ouabain- and bumetanide-insensitive $\mathrm{K}^{+}$"leak" flux was $2.10 \pm 0.43 \mu \mathrm{mol} \mathrm{K} \mathrm{K}^{+} \cdot \mathrm{g}$ protein ${ }^{-1} \cdot \mathrm{min}^{-1}$. Thus the $\mathrm{Na}^{+}-\mathrm{K}^{+}-\mathrm{Cl}^{-}$cotransporter and $\mathrm{Na}^{+}-\mathrm{K}^{+}$-ATPase activities together account for $\sim 90 \%$ of total $\mathrm{K}^{+}$influx in these cells.

ATP measurements. ATP was measured enzymatically by luciferin/ luciferase-generated luminescence. For these measurements, CMEC monolayers on 24-well plates were treated with varying levels of $\mathrm{O}_{2}$ in the hypoxia chamber as described for $\mathrm{K}^{+}$influx assays. At the end of each experiment, assay medium was aspirated, and the cells were immediately lysed using ice-cold $0.1 \mathrm{~N} \mathrm{NaOH}$ containing $25 \mathrm{mM}$ HEPES ( $\mathrm{pH}$ 12.7). After $1 \mathrm{~min}$, cell extracts were collected and stored at $-80^{\circ} \mathrm{C}$. For assay of ATP, lysates were sonicated for $10 \mathrm{~min}$ and the lysate $\mathrm{pH}$ was adjusted to 7.8 with $1 \mathrm{~N} \mathrm{HCl}$ containing $25 \mathrm{mM}$ HEPES. Luminescence was measured at $25^{\circ} \mathrm{C}$ using a MicroLumat Plus luminometer (EG\&G Berthold). For these assays, ATP enzyme/ buffer was automatically added (by luminometer) to each lysate solution. ATP enzyme/buffer contained (in $\mathrm{mM}$ ) 25 HEPES, 5 $\mathrm{MgSO}_{4}, 0.5$ EDTA, 0.5 dithiothreitol, 0.05 coenzyme A, plus $1 \mathrm{mg} / \mathrm{ml}$ BSA and $0.1 \mathrm{mg} / \mathrm{ml}$ luciferin/luciferase in glycine buffer (Sigma, St. Louis, MO), $\mathrm{pH}$ 7.8. Luminescence was measured $2 \mathrm{~s}$ after the addition of ATP buffer. The total protein in each well was measured using BCA assay, and luminescence was expressed as micromoles of ATP per gram of protein.

Gel electrophoresis and Western blot analysis. Cell lysates of CMEC monolayers were prepared for Western blot analysis as described by us previously $(38,43,46)$ with some modifications. For these studies, CMECs on 24-well plates were exposed to varying levels of hypoxia in HEPES DMEM for desired times as described for $\mathrm{K}^{+}$influx methods. At the end of the treatment period, wells were washed three times with ice-cold PBS containing $5 \mathrm{mM}$ EDTA (PBS/EDTA) plus protease inhibitors and phosphatase inhibitors (38, 
43, 46). Cells were then lysed in PBS/EDTA containing 1\% SDS plus protease and phosphatase inhibitors. The protein content of each lysate was analyzed in triplicate by BCA assay (Pierce) to ensure equal loading onto gel lanes. Lysate samples and prestained molecular weight markers (Bio-Rad, Hercules, CA) were denatured in SDS reducing buffer containing dithiothreitol (Invitrogen NuPage, Carlsbad, CA), heated to $70^{\circ} \mathrm{C}$ for $10 \mathrm{~min}$ and loaded onto precast $7.5 \%$ Tris-glycine gels (Cambrex PAGEr, Gold Precast, Rockland, ME) for electrophoretic separation (Bio-Rad Mini-PROTEAN II). Resolved proteins were transferred to polyvinylidene difluoride membranes with the use of a Bio-Rad Transblot apparatus. Blots were subsequently incubated for $1 \mathrm{~h}$ at room temperature in PBS containing 7.5\% milk and $0.1 \%$ Tween (PBS/milk) and then incubated for $1 \mathrm{~h}$ with T4 monoclonal antibody to detect $\mathrm{Na}^{+}-\mathrm{K}^{+}-\mathrm{Cl}^{-}$cotransporter (NKCC) protein (29) and monoclonal $\beta$-actin antibody (Abcam, Cambridge, MA) in PBS/milk solution. Blots were washed with PBS-Tween and then incubated for $1 \mathrm{~h}$ with secondary antibody (horseradish peroxidase-conjugated goat anti-mouse $\mathrm{IgG}$ ), and bound secondary antibody was visualized with the use of an enhanced chemiluminescence assay (Amersham Biosciences) and a FujiFilm LAS-3000 Imaging System (Medford, UK). Band intensity was quantified using ImageQuant software (Molecular Dynamics, Sunnyvale, CA). For detection of phosphorylated NKCC (p-NKCC) protein, we used the polyclonal R5 antibody raised against a diphosphopeptide containing $\mathrm{Thr}^{212}$ and $\mathrm{Thr}^{217}$ of human NKCC as described previously $(13,14)$, together with horseradish peroxidase-conjugated goat anti-rabbit $\mathrm{IgG}$ as secondary antibody. The R5 antibody recognizes p-NKCC over the nonphosphorylated NKCC protein with high affinity and specificity. This antibody has been shown to detect NKCC phosphorylation effectively, with a quantitative relationship between the level of phosphorylation detected by the R5 antibody vs. ${ }^{32} \mathrm{P}$ incorporation into T4-immunopreciptated protein (13). For both NKCC (T4) and p-NKCC (R5) Western blots, $\beta$-actin was used as a loading control. We analyzed data both with and without normalizing to the $\beta$-actin bands and found no difference in the results.

Cell volume measurements. Intracellular volume was determined by radioisotopic evaluation of intracellular water space using $\left[{ }^{3} \mathrm{H}\right]-3$ O-methyl-D-glucose and $\left[{ }^{14} \mathrm{C}\right]$-sucrose as markers of total and extracellular water space, respectively, by modification of previously described methods $(3,26,27)$. CMECs grown on 24-well plates were exposed to varying levels of hypoxia for varying times in HEPES DMEM with or without glucose as described for $\mathrm{K}^{+}$influx methods. During the last $20 \mathrm{~min}$ of hypoxia treatment, $0.25 \mu \mathrm{Ci} / \mathrm{ml}\left[{ }^{3} \mathrm{H}\right]-3-\mathrm{O}-$ methyl-D-glucose and $\left[{ }^{14} \mathrm{C}\right]$-sucrose were added to the wells. (Isotopic equilibration is achieved within $10 \mathrm{~min}$ under our assay conditions.) The assay was terminated by aspirating and rapidly rinsing wells with ice-cold $\mathrm{MgCl}_{2}$. The dishes were air dried and then extracted with $0.1 \%$ SDS for quantification of radioactivity and protein. Intracellular volume was calculated as the difference between water space determined for $\left[{ }^{3} \mathrm{H}\right]-3-\mathrm{O}-$ methyl-D-glucose (a measure of intracellular plus trapped extracellular volume), and water space was determined for $\left[{ }^{14} \mathrm{C}\right]$-sucrose (a measure of trapped extracellular volume). For experiments in which we used HEPES DMEM without glucose, nonradioactive 3-O-methyl-D-glucose was included in the medium in place of glucose $(3,26,27)$.

Materials. DMEM and L-glutamine were purchased from GIBCOBRL (Grand Island, NY) and gentamicin was from AG Scientific (San Diego, CA). FBS and calf serum were obtained from HyClone (Logan, UT). Horse serum and oligomycin were from Sigma (St. Louis MO). Bumetanide and ouabain were from ICN Biomedicals (Costa Mesa, CA), ${ }^{86} \mathrm{Rb}$ was from Perkin-Elmer (Welles, MA), and $\left[{ }^{3} \mathrm{H}\right]-3-\mathrm{O}$-methyl-D-glucose and $\left[{ }^{14} \mathrm{C}\right]$-sucrose were purchased from Dupont NEN (Boston, MA). Arginine vasopressin (AVP) was purchased from Peninsula Laboratories (a division of Bachem, San Carlos, CA). T4 monoclonal antibody was obtained from the University of Iowa Developmental Studies Hybridoma Bank (Iowa City, IA). $\beta$-Actin antibody was purchased from Abcam (Cambridge, MA).
Secondary antibodies were from Zymed Laboratories (South San Francisco, CA).

Statistics. All values shown in figures and tables are means \pm SE. In each experiment, at least 3-4 replicates were taken for each condition and averages of replicates were used to calculate $\mathrm{K}^{+}$influx, ATP content, or intracellular volume. Thus the $n$ values used for statistics represent the number of experiments conducted. Data shown were analyzed for significance using a paired Student's $t$-test or ANOVA as indicated. Differences with $P$ values $<0.05$ were considered statistically significant.

\section{RESULTS}

Hypoxia stimulates $\mathrm{CMEC} \mathrm{Na}^{+}-\mathrm{K}^{+}-\mathrm{Cl}^{-}$cotransporter activity in both the presence and absence of glucose and pyruvate. To evaluate the hypothesis that hypoxia, as a component of cerebral ischemia, stimulates activity of the $\mathrm{BBB} \mathrm{Na}{ }^{+}-\mathrm{K}^{+}$$\mathrm{Cl}^{-}$cotransporter to promote edema formation, we first tested the effects of exposing cultured CMECs to varying levels of hypoxia. As shown in Fig. $1 A$, we found that exposing the cells for just $30 \mathrm{~min}$ to $7.5 \% \mathrm{O}_{2}$, a modest level of hypoxia, significantly increased $\mathrm{Na}^{+}-\mathrm{K}^{+}-\mathrm{Cl}^{-}$cotransport activity above that found in cells exposed to normoxia $\left(19 \% \mathrm{O}_{2}\right.$ in these studies as described in MATERIALS AND METHODS). CMEC cotransport activity was also significantly elevated after a 30-min exposure to more severe levels of hypoxia, including $3 \%, 2 \%$, and $0.5 \% \mathrm{O}_{2}\left(16 \%, 11 \%\right.$, and $3 \%$, of normoxic $\mathrm{O}_{2}$, respectively). For these experiments, cotransporter activity was evaluated as bumetanide-sensitive, ouabain-insensitive $\mathrm{K}^{+}$influx, as described in MATERIALS AND METHODS. In a few experiments, we also evaluated cotransporter activity in the absence of ouabain and found that 30-min exposures of CMEC to $7.5 \% \mathrm{O}_{2}$ or $3 \% \mathrm{O}_{2}$ increased cotransporter activity by $30.9 \pm 4.5 \%$ and $44.5 \pm 6.1 \%$, respectively (means $\pm \mathrm{SE}, n=4$ and 5 , respectively), responses similar to those found when cotransporter activity was measured in the presence of ouabain (Fig. 1). Our hypothesis that hypoxia stimulation of $\mathrm{Na}^{+}-\mathrm{K}^{+}-\mathrm{Cl}^{-}$ cotransporter activity contributes to edema formation during stroke predicts that $\mathrm{Na}^{+}$entering the $\mathrm{BBB}$ endothelial cells at the luminal membrane exits via the abluminal $\mathrm{Na}^{+}-\mathrm{K}^{+}$ATPase. However, hypoxia has been found to reduce ATP levels in many cells, with the severity depending on the degree of hypoxia and the time of exposure. It is therefore possible that although hypoxia stimulates the $\mathrm{BBB} \mathrm{Na}^{+}-\mathrm{K}^{+}-\mathrm{Cl}^{-}$cotransporter, it could decrease activity of the ATP-dependent $\mathrm{Na}^{+}-\mathrm{K}^{+}$-ATPase if ATP levels fell to sufficiently low levels. Thus, in addition to assessing the effects of hypoxia on $\mathrm{Na}^{+}$$\mathrm{K}^{+} \mathrm{Cl}^{-}$cotransporter activity, in each experiment we also assessed activity of the $\mathrm{Na}^{+}-\mathrm{K}^{+}$-ATPase. Figure $1 B$ shows that exposing CMEC to 30 min of $7.5 \% \mathrm{O}_{2}$ down to $0.5 \% \mathrm{O}_{2}$ did not significantly alter $\mathrm{Na}^{+}-\mathrm{K}^{+}$-ATPase activity of the cells. It should be noted that, as measured herein, $\mathrm{Na}^{+}-\mathrm{K}^{+}-\mathrm{Cl}^{-}$cotransporter and $\mathrm{Na}^{+}-\mathrm{K}^{+}$-ATPase activities are not coupled together, because the cotransporter as assessed in the presence of ouabain and ATPase was measured in the presence of bumetanide. This was done to assess the effects of hypoxia on the cotransporter and the pump independently of each other. In 12 experiments, we evaluated the effect of hypoxia on $\mathrm{Na}^{+}$$\mathrm{K}^{+}$-ATPase activity, assessed as ouabain-sensitive $\mathrm{K}^{+}$(in the absence of bumetanide, i.e., with the cotransporter functioning). We found that $30 \mathrm{~min}$ of $7.5 \% \mathrm{O}_{2}$ increased $\mathrm{Na}^{+}-\mathrm{K}^{+}$ATPase activity over that observed with $19 \% \mathrm{O}_{2}$, from $7.72 \pm$ 
A

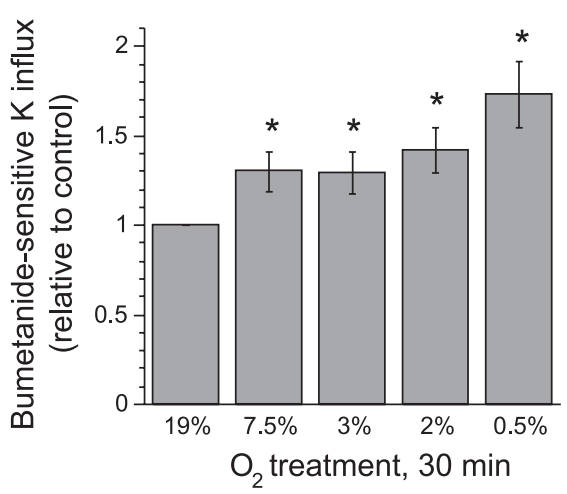

B

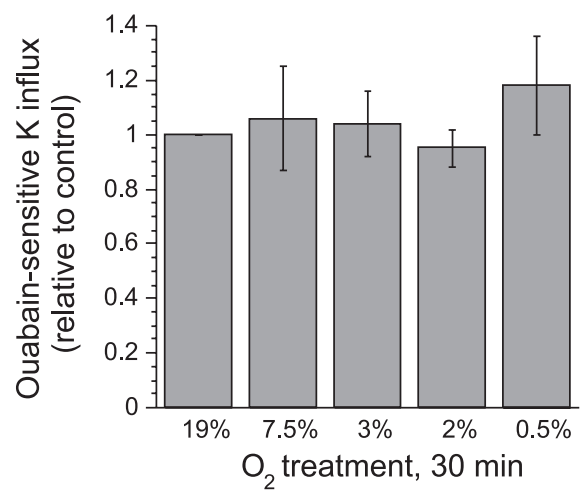

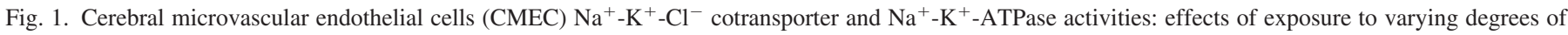

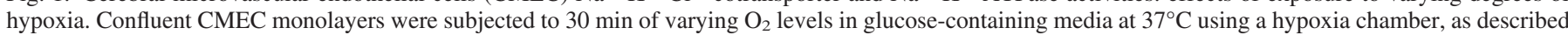

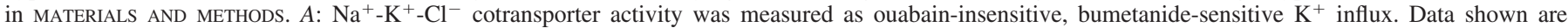

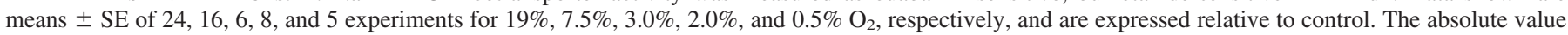

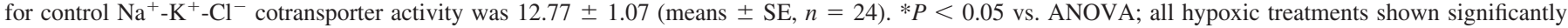

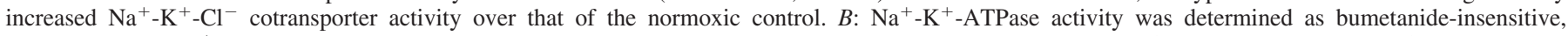

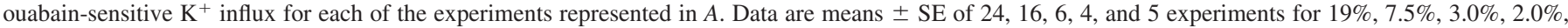

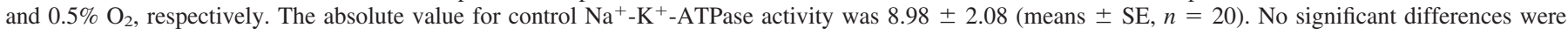
found among the groups by ANOVA.

1.15 to $9.49 \pm 0.98 \mu \mathrm{mol} \mathrm{K} \mathrm{K}^{+} \cdot \mathrm{g} \operatorname{protein}^{-1} \cdot \min ^{-1}$ (means \pm SE; $P<0.05$ by paired $t$-test). This finding, which suggests that the $\mathrm{Na}^{+}-\mathrm{K}^{+}-\mathrm{Cl}^{-}$cotransporter and $\mathrm{Na}^{+}-\mathrm{K}^{+}$-ATPase are functionally coupled, is addressed further in the DISCUSSION.

In subsequent experiments examining hypoxia effects on the CMEC $\mathrm{Na}^{+}-\mathrm{K}^{+}-\mathrm{Cl}^{-}$cotransporter and $\mathrm{Na}^{+}-\mathrm{K}^{+}$-ATPase, we focused on two $\mathrm{O}_{2}$ levels: $7.5 \% \mathrm{O}_{2}$, a moderate level of hypoxia that might be found in the penumbral region of focal ischemia, and $2 \% \mathrm{O}_{2}$, a more severe level of hypoxia that can occur in the ischemic core (2). First, we tested the effect of exposing CMEC to $7.5 \% \mathrm{O}_{2}$ over a time course of 30 to $180 \mathrm{~min}$. This was done to determine whether the cotransporter is stimulated by hypoxia with a time course consistent with ischemia-induced edema formation, i.e., significant edema formation is observed within an hour from the onset of ischemia and continues throughout the time that the BBB remains intact (through $4-6$ h) $(6,31)$. As shown in Fig. $2 A$,
CMEC Na ${ }^{+}-\mathrm{K}^{+}-\mathrm{Cl}^{-}$cotransporter activity was significantly increased following 30 to $120 \mathrm{~min}$ of exposure to $7.5 \% \mathrm{O}_{2}$. By 180 min, cotransporter activity fell toward the control (normoxia) activity level. At the same time, activity of the $\mathrm{Na}^{+}-\mathrm{K}^{+}$-ATPase was unaltered by 30 - to 180 -min exposures to $7.5 \% \mathrm{O}_{2}$ (Fig. $2 B$ ). We next examined the effects of $2 \% \mathrm{O}_{2}$ on activity of the CMEC cotransporter. Figure $3 A$ shows that $\mathrm{Na}^{+}-\mathrm{K}^{+}-\mathrm{Cl}^{-}$cotransporter activity was significantly increased after $30 \mathrm{~min}$ of exposure to $2 \% \mathrm{O}_{2}$. With this more severe hypoxia treatment, after 120 and $240 \mathrm{~min}$, cotransporter activity fell back to levels not significantly different from control $\left(19 \% \mathrm{O}_{2}\right)$. In these same experiments, activity of the CMEC $\mathrm{Na}^{+}-\mathrm{K}^{+}$-ATPase was not significantly altered by 30 - to $240-$ min exposure to $2 \% \mathrm{O}_{2}$ (Fig. $3 B$ ).

The experiments presented in Figs. 1-3 were all conducted in media containing both glucose and pyruvate (as described in MATERIALS AND METHODS). To determine whether CMEC cotrans-
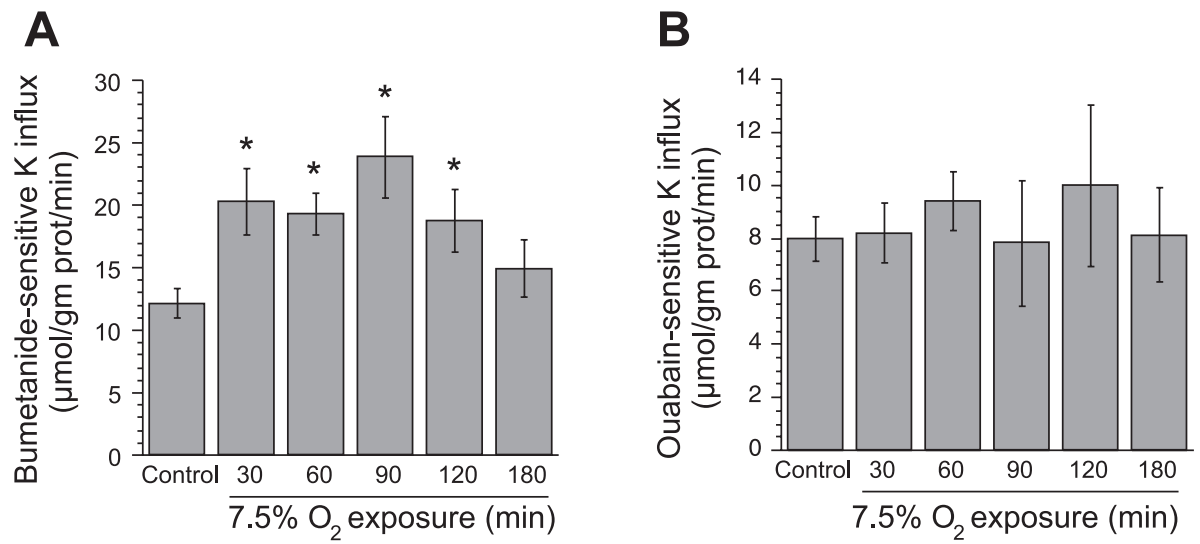

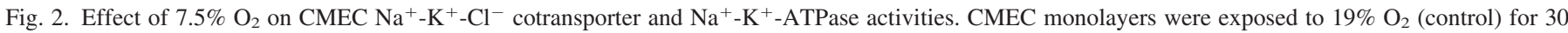

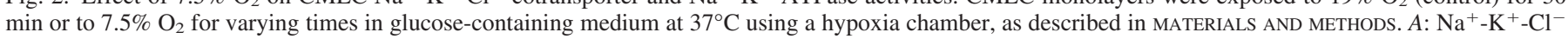

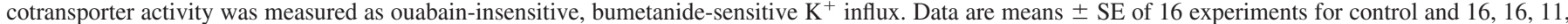

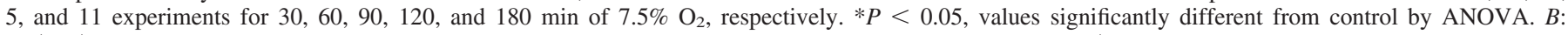

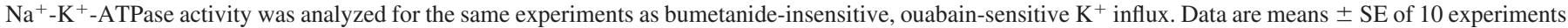

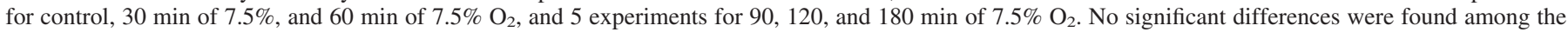
groups by ANOVA. 
Fig. 3. Effect of $2 \% \mathrm{O}_{2}$ on $\mathrm{CMEC} \mathrm{Na}{ }^{+}-\mathrm{K}^{+}-\mathrm{Cl}^{-}$ cotransporter activity. CMEC monolayers were exposed to $19 \% \mathrm{O}_{2}$ (control) for $30 \mathrm{~min}$ or to $2 \%$ $\mathrm{O}_{2}$ for varying times in glucose-containing medium. $A$ : $\mathrm{Na}^{+}-\mathrm{K}^{+}-\mathrm{Cl}^{-}$cotransporter activity was measured as ouabain-insensitive, bumetanidesensitive $\mathrm{K}^{+}$influx. Data are means $\pm \mathrm{SE}$ of 6 experiments for all conditions, respectively. $* P<$ 0.05 , significant difference from control by ANOVA.

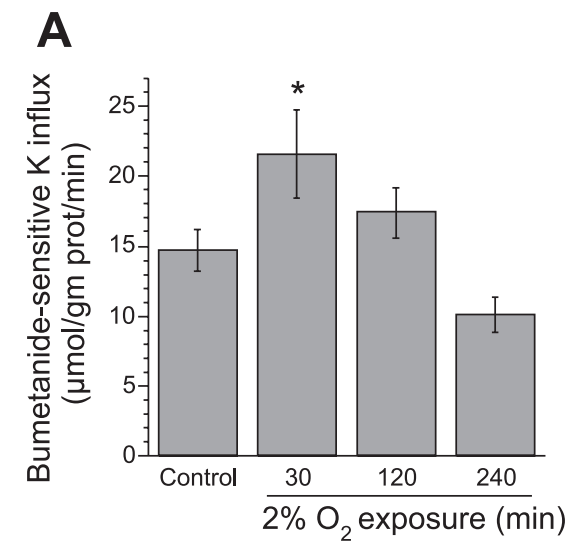

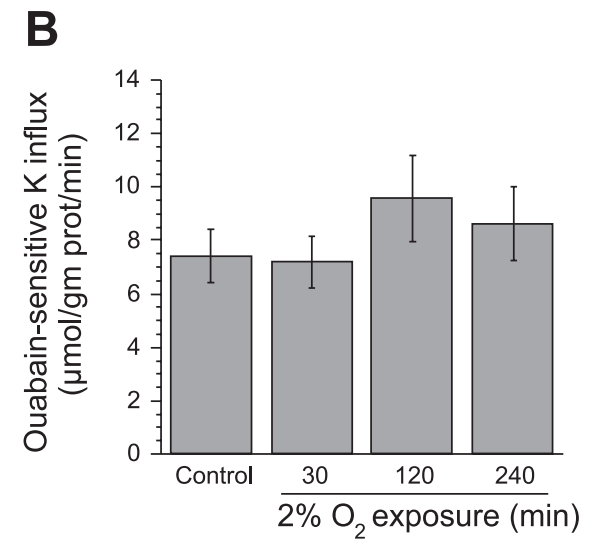

porter activity is stimulated by hypoxia in the absence as well as the presence of glucose, we exposed CMECs to $7.5 \% \mathrm{O}_{2}$ in glucose-free media for a time course of 30 to $180 \mathrm{~min}$. In these experiments, we first used media lacking glucose but containing pyruvate and obtained results very similar to those observed for glucose plus pyruvate-containing media, as shown in Table 1 (compare data of Fig. $2 A$ and Table 1, left column). We also found that, as with experiments conducted in the presence of both glucose and pyruvate, $7.5 \% \mathrm{O}_{2}$ exposures of 30 to $120 \mathrm{~min}$ in glucose-free media caused no change in $\mathrm{Na}^{+}-\mathrm{K}^{+}$-ATPase activity (data not shown). We next tested the effects of exposing CMECs to $7.5 \% \mathrm{O}_{2}$ in media lacking both pyruvate and glucose and observed that even under these conditions, this moderate level of hypoxia caused significant stimulation of cotransporter activity after 30-, 60-, or 90-min exposure, but not after a 180-min exposure (Table 1). However, whereas the profile of cotransporter stimulation by $7.5 \% \mathrm{O}_{2}$ was similar for all media tested, regardless of whether glucose and/or pyruvate were present, the overall cotransporter activity values were higher in media lacking both glucose and pyruvate. In fact, simply removing pyruvate from the glucose-free media under normoxic (control) conditions increased cotransporter activity 2.6-fold. Similarly, cotransporter activity in pyruvate- and glucose-free medium was increased 2.4- to 2.6-fold over that found in pyruvate-containing media (either with or

Table 1. CMEC $\mathrm{Na}^{+}-\mathrm{K}^{+}-\mathrm{Cl}^{-}$cotransporter activity: effects of hypoxia in glucose-free media with or without pyruvate

\begin{tabular}{ccc}
\hline \hline & \multicolumn{2}{c}{$\begin{array}{c}\text { Bumetanide-Sensitive } \mathrm{K}^{+} \text {Influx, } \mu \mathrm{mol} \cdot \mathrm{g} \\
\text { protein }^{-1} \cdot \mathrm{min}^{-1}\end{array}$} \\
\cline { 2 - 3 } & $\begin{array}{c}\text { - Glucose } \\
\text { + Pyruvate }\end{array}$ & $\begin{array}{c}\text { - Glucose } \\
7.5 \% \mathrm{O}_{2} \text { Treatment, min }\end{array}$ \\
\hline Control & $12.99 \pm 0.85$ & $34.04 \pm 2.27$ \\
30 & $20.49 \pm 3.03^{*}$ & $54.24 \pm 8.5^{*}$ \\
60 & $23.05 \pm 1.75^{*}$ & $55.30 \pm 6.90^{*}$ \\
90 & $21.79 \pm 4.54^{*}$ & $52.78 \pm 5.38^{*}$ \\
120 & $19.58 \pm 4.49$ & $\mathrm{ND}$ \\
180 & $11.36 \pm 1.31$ & $30.10 \pm 4.14$
\end{tabular}

Data are means \pm SE of 5 experiments for glucose-free media and 6 experiments for glucose- and pyruvate-free media. CMEC, cerebral microvascular endothelial cells; ND, not determined. CMEC monolayers were exposed to $19 \% \mathrm{O}_{2}$ (control) for $30 \mathrm{~min}$ or to $7.5 \% \mathrm{O}_{2}$ for varying times in glucose-free medium either containing or lacking pyruvate in a hypoxia chamber, as described in MATERIALS AND METHODS. $\mathrm{Na}^{+}-\mathrm{K}^{+}-\mathrm{Cl}^{-}$cotransporter activity was measured as ouabain-insensitive, bumetanide-sensitive $\mathrm{K}^{+}$influx. ${ }^{*} P<0.05$, by ANOVA, significantly different from their respective control values. without glucose) after 30 - to 90 -min exposures to $7.5 \% \mathrm{O}_{2}$. This finding is considered further in the DISCUSSION.

In previous studies, we have shown that AVP, a factor present during cerebral ischemia, is a potent stimulator of CMEC Na${ }^{+}-\mathrm{K}^{+}-\mathrm{Cl}^{-}$cotransporter activity (34). During ischemia, $\mathrm{BBB}$ endothelial cells are exposed to a combination of factors, including the presence of both AVP and hypoxia. Thus, in the present studies, we evaluated the combined effects of AVP and hypoxia on CMEC cotransporter activity. In these experiments, we used media containing glucose and pyruvate. As shown in Fig. 4, cotransporter activity of cells exposed to $30 \mathrm{~min}$ of $7.5 \% \mathrm{O}_{2}$ plus $10 \mathrm{nM}$ AVP (present during the last 7 min of hypoxia exposure) was not significantly different from cotransporter activity observed with hypoxia or AVP alone. Thus CMEC cotransporter activity is significantly elevated in the combined presence of AVP and hypoxia, although the stimulatory effects of these two factors do not appear to be additive.

Effects of hypoxia treatments that stimulate CMEC $\mathrm{Na}^{+}-\mathrm{K}^{+}$ $\mathrm{Cl}^{-}$cotransporter activity on ATP content and cell volume. A commonly held assumption is that hypoxia, or at least hypoxia and aglycemia in combination, can cause a significant reduction of cellular ATP content in BBB endothelial cells. To address this issue, we evaluated ATP content of CMECs after exposing them to either $7.5 \% \mathrm{O}_{2}$ or $2 \% \mathrm{O}_{2}$ in the presence or

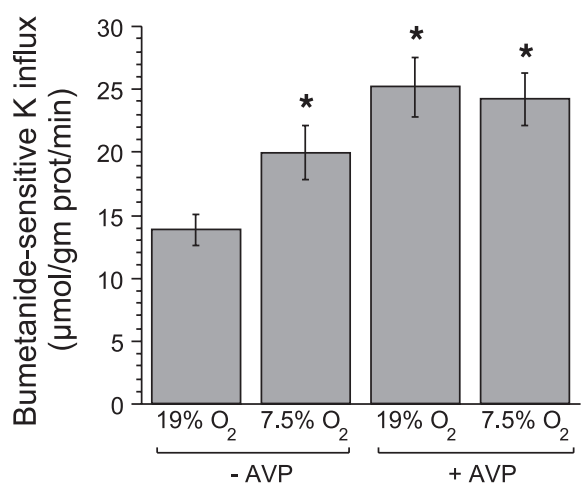

Fig. 4. $\mathrm{CMEC} \mathrm{Na}^{+}-\mathrm{K}^{+}-\mathrm{Cl}^{-}$cotransport activity: combined effects of hypoxia and arginine vasopressin (AVP). CMEC monolayers were exposed to either $19 \%$ (normoxia) or $7.5 \% \mathrm{O}_{2}$ for $23 \mathrm{~min}$ and then exposed to 0 or $100 \mathrm{nM} \mathrm{AVP}$ for $7 \mathrm{~min}$ in the same normoxic or hypoxic media. $\mathrm{Na}^{+}-\mathrm{K}^{+}-\mathrm{Cl}^{-}$cotransporter activity was then assessed as described in MATERIALS AND METHODS. Data are means $\pm \mathrm{SE}$ of 3 experiments each. $* P<0.05$, significantly different from control $\left(19 \% \mathrm{O}_{2}\right.$ without AVP) by ANOVA. 
Table 2. CMEC ATP content following $2 \% \mathrm{O}_{2}$ treatment

\begin{tabular}{ccc}
\hline \hline & \multicolumn{2}{c}{ ATP, $\mu$ mol/g protein } \\
\cline { 2 - 3 } Hypoxia Treatment & + Glucose & - Glucose \\
\hline Control & $17.07 \pm 1.47$ & $19.20 \pm 1.69$ \\
$30 \mathrm{~min}$ & $17.61 \pm 1.46$ & $18.07 \pm 1.70$ \\
$2 \mathrm{~h}$ & $17.97 \pm 1.66$ & $19.10 \pm 1.87$ \\
$4 \mathrm{~h}$ & $18.15 \pm 1.91$ & $19.74 \pm 2.21$ \\
$24 \mathrm{~h}$ & $10.33 \pm 1.36^{*}$ & $10.84 \pm 0.57^{*}$ \\
\hline
\end{tabular}

Values are means $\pm \mathrm{SE} ; n=5$ experiments each. Confluent CMEC monolayers were exposed to either $19 \% \mathrm{O}_{2}$ for $30 \mathrm{~min}$ (control) or to $2 \%$ $\mathrm{O}_{2}$ for $30 \mathrm{~min}$ up to $24 \mathrm{~h}$ in either glucose-containing or glucose-free media. $* P<0.05$, significantly different from control values by Student's paired $t$-test.

absence of glucose for $30 \mathrm{~min}$ up to $24 \mathrm{~h}$. We found that treating cells with $2 \% \mathrm{O}_{2}$ for $30 \mathrm{~min}$ to $4 \mathrm{~h}$, whether in the presence or absence of glucose, did not significantly reduce ATP content of the cells. However, treating the cells with $2 \%$ $\mathrm{O}_{2}$ for $24 \mathrm{~h}$ did cause a significant reduction of ATP content, although by only $43-45 \%$ (Table 2). Exposing the cells to $7.5 \% \mathrm{O}_{2}$ for 30 min to $3 \mathrm{~h}$ also did not cause a change in ATP content, whether in the presence or absence of glucose (data not shown). These findings indicate that hypoxia stimulates CMEC cotransporter activity in a manner that is independent of a fall in cellular ATP content.

Previous studies $(20,21)$ of rat brain microvascular endothelial cells demonstrated that treating the cells with oligomycin $(1 \mu \mathrm{g} / \mathrm{ml}$ for up to $60 \mathrm{~min})$ to induce chemical hypoxia caused an increase in $\mathrm{Na}^{+}-\mathrm{K}^{+}-\mathrm{Cl}^{-}$cotransporter activity while also decreasing ATP content of the cells by $60 \%$. In experiments conducted to determine whether our bovine CMEC also exhibited an oligomycin-induced stimulation of cotransporter activity, we exposed the cells to either 30 or $60 \mathrm{~min}$ of oligomycin in doses ranging from 0.1 to $5 \mu \mathrm{g} / \mathrm{ml}$. We found that cotransporter activity of the bovine CMEC was maximally stimulated by $30 \mathrm{~min}$ of $1 \mu \mathrm{g} / \mathrm{ml}$ oligomycin from a control level of $9.33 \pm 0.67$ to $16.34 \pm 0.88 \mu \mathrm{mol} \cdot \mathrm{g}$ protein ${ }^{-1} \cdot \mathrm{min}^{-1}$ after oligomycin treatment (means $\pm \mathrm{SE}, n=3$; data not shown). Thus the bovine CMEC cotransporter can be stimulated by chemical hypoxia as well as true hypoxia. In our studies, a 30-min oligomycin treatment reduced CMEC ATP content to $72.3 \pm 0.7 \%$ of control $(n=3)$.

Our hypothesis predicts that the hypoxia stimulation of BBB $\mathrm{Na}^{+}-\mathrm{K}^{+}-\mathrm{Cl}^{-}$cotransporter activity contributes to secretion of $\mathrm{Na}^{+}, \mathrm{Cl}^{-}$, and water into the brain, contributing to edema formation during the early stages of cerebral ischemia. It is possible that increased uptake of $\mathrm{Na}^{+}$and $\mathrm{Cl}^{-}$from blood into the BBB endothelial cells via hypoxia-elevated $\mathrm{Na}^{+}-\mathrm{K}^{+}-\mathrm{Cl}^{-}$ cotransporter activity, if not sufficiently coupled to abluminal $\mathrm{Na}^{+}$and $\mathrm{Cl}^{-}$efflux pathways, could cause swelling of the BBB endothelial cells rather than secretion of $\mathrm{Na}^{+}$and $\mathrm{Cl}^{-}$ into the brain. To test this possibility, we assessed the effects of hypoxia on CMEC intracellular volume using radioisotopic equilibration of $\left[{ }^{3} \mathrm{H}\right]-3-\mathrm{O}-m e t h y l-D-g l u c o s e$ and $\left[{ }^{14} \mathrm{C}\right]$-sucrose, as described in MATERIALS AND METHODS. Figure $5 \mathrm{~A}$ shows that exposing CMEC for $2 \mathrm{~h}$ to $7.5 \% \mathrm{O}_{2}$ down to $1 \% \mathrm{O}_{2}$ did not cause a significant change in intracellular volume compared with the normoxic $\left(19 \% \mathrm{O}_{2}\right)$ control. When we exposed the cells to $7.5 \% \mathrm{O}_{2}$ for times ranging from 1 to $5 \mathrm{~h}$, we observed that CMEC intracellular volume did not significantly increase compared with that of the normoxic control until after 4- and 5-h exposures (Fig. 5B).

Effects of hypoxia on $\mathrm{CMEC} \mathrm{Na}^{+}-\mathrm{K}^{+}-\mathrm{Cl}^{-}$cotransporter protein phosphorylation and abundance. In the present studies, we conducted a preliminary investigation of cellular mechanisms that may underlie the hypoxia-induced increase in CMEC cotransporter activity. For this, we focused on two questions: 1) whether hypoxia alters the amount of $\mathrm{Na}^{+}-\mathrm{K}^{+}-$ $\mathrm{Cl}^{-}$cotransporter protein in the cells and 2) whether hypoxia causes phosphorylation of the cotransporter. With respect to the first issue, we have shown previously that CMEC cotransporter activity is increased after exposure of the cells to astrocyte-conditioned medium in a manner associated with increased abundance of the $\mathrm{Na}^{+}-\mathrm{K}^{+}-\mathrm{Cl}^{-}$cotransporter protein (which we denote herein as NKCC) (43) and also that AVP can both stimulate $\mathrm{CMEC} \mathrm{Na}^{+}-\mathrm{K}^{+}-\mathrm{Cl}^{-}$cotransporter activity and increase the amount of NKCC in the cells (37). Thus, in the present study, we evaluated the effect of hypoxia on NKCC abundance using Western blot analysis with the T4 monoclonal antibody that recognizes NKCC. Figure 6 shows that neither treating the cells with $7.5 \% \mathrm{O}_{2}$ for 30 to 180 min nor subjecting the cells to the more extreme conditions of $2 \% \mathrm{O}_{2}$ for 120 or 240 min significantly altered NKCC abundance. This suggests that at least during the early stages of cerebral edema formation in stroke, hypoxia-increased cotransporter activity does not involve an increase in NKCC abundance. With respect to the possibility that hypoxia stimulation of the CMEC cotransporter involves phosphorylation of the cotransporter protein, we have shown previously that the phosphatase inhibitor calyculin A and hyperosmotic solutions both stimulate activity of the $\mathrm{Na}^{+}-$
A

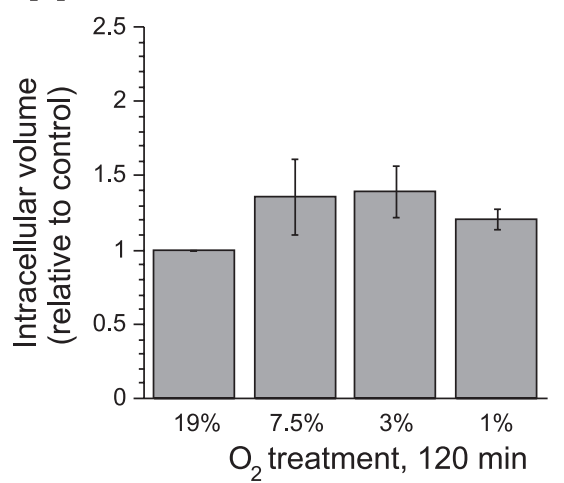

B

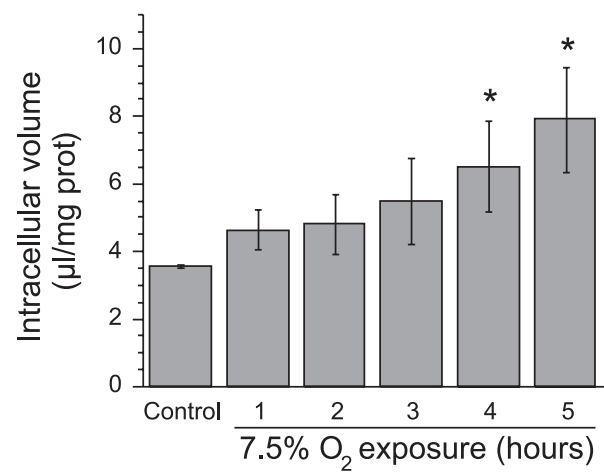

Fig. 5. CMEC intracellular volume: effects of varying hypoxia exposures. $A$ : CMEC monolayers were subjected to $2 \mathrm{~h}$ of varying $\mathrm{O}_{2}$ levels in glucose-containing media at $37^{\circ} \mathrm{C}$ using a hypoxia chamber as described in MATERIALS AND METHODS. Intracellular volume was then assessed using ${ }^{3}[\mathrm{H}]-3-\mathrm{O}-$ methyl-D-glucose equilibration. Values are means $\pm \mathrm{SE}$ of 3 experiments for all conditions and are expressed relative to control. The absolute value for the $19 \% \mathrm{O}_{2}$ control was $3.31 \pm 0.132 \mu \mathrm{l} \cdot \mathrm{mg} \operatorname{protein}^{-1}$ (means $\pm \mathrm{SE}$ ). No significant differences were found among the groups by ANOVA. $B$ : CMEC monolayers were subjected to $7.5 \% \mathrm{O}_{2}$ in a hypoxia chamber for 1 to $5 \mathrm{~h}$ in the same media used in $A$. Data are means $\pm \mathrm{SE}$ of 3 experiments. $* P<0.05$ significantly different from control by ANOVA. 
A

Fig. 6. Abundance of CMEC $\mathrm{Na}^{+}-\mathrm{K}^{+}-\mathrm{Cl}^{-}$cotransporter protein (NKCC) after exposures to hypoxia and AVP. CMEC were exposed to $19 \%$ $\mathrm{O}_{2}$ (control) for $30 \mathrm{~min}$ or to $7.5 \% \mathrm{O}_{2}$ for 30 , 90 , or $180 \mathrm{~min}(A$ and $B)$ or $2 \% \mathrm{O}_{2}$ for 120 or $240 \mathrm{~min}(C$ and $D)$ in glucose-containing media at $37^{\circ} \mathrm{C}$ using a hypoxia chamber as described in MATERIALS AND METHODS. The abundance of NKCC protein was then determined for each condition using Western blot analysis. Representative Western blots of NKCC abundance for $7.5 \%$ and $2 \% \mathrm{O}_{2}$ are shown in $A$ and $C$, respectively. In these experiments, $\beta$-actin was used as a loading control. NKCC abundance was quantitated by ImageQuant software analysis of Western blots and is shown in $B$ and $D$ for $7.5 \%$ and $2 \% \mathrm{O}_{2}$, respectively. Values are means \pm SE of 7 experiments for each condition. No significant differences were found in NKCC abundance between control and any of the hypoxia exposures by Student's paired $t$ tests.

B
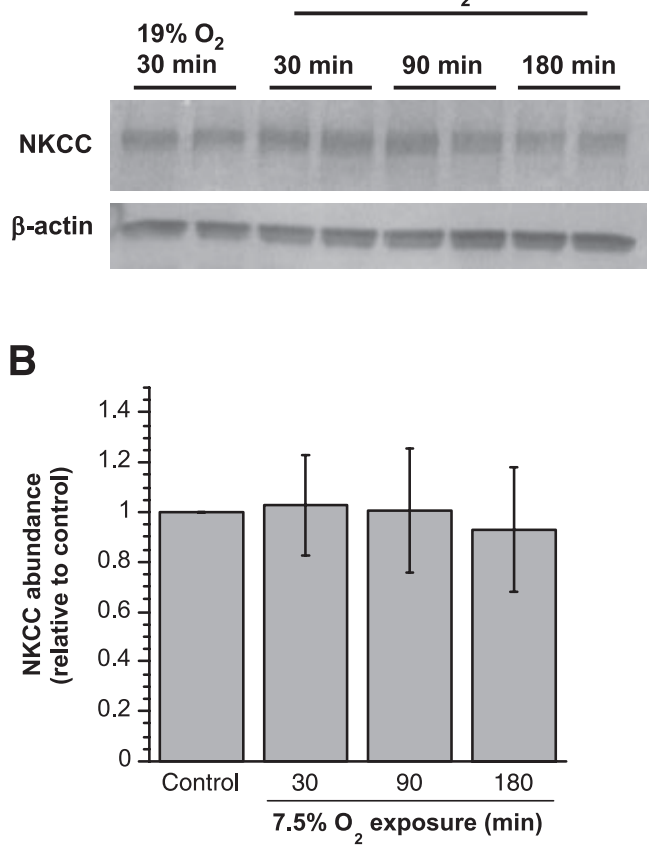

C

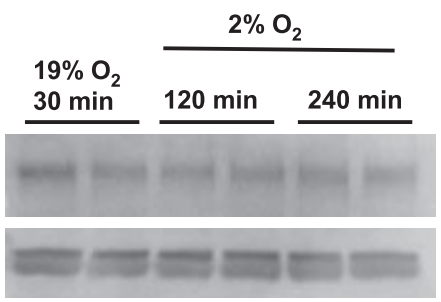

$\beta$-actin

NKCC

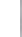

D

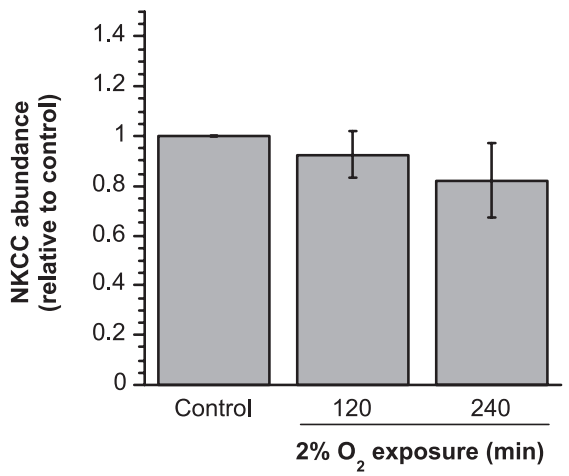

$\mathrm{K}^{+}-\mathrm{Cl}^{-}$cotransporter and also increase phosphorylation of the cotransporter protein (44). To determine whether hypoxia also increases NKCC phosphorylation, in the present study, we exposed CMECs to hypoxia for varying times and then used Western blot analysis with the R5 antibody that specifically recognizes phosphorylated NKCC. As shown in Fig. 7, exposing the cells to $7.5 \% \mathrm{O}_{2}$ for 30 or $90 \mathrm{~min}$ did indeed cause a significant increase in abundance of phosphorylated NKCC (p-NKCC) in the CMEC. Specifically, increases in p-NKCC abundance of 1.62- and 1.76-fold were observed after 30- and 90-min hypoxia exposures. In these experiments, a mean 1.96fold increase in p-NKCC following 180-min exposure to $7.5 \%$ $\mathrm{O}_{2}$ was observed. However, this was not found to be statistically different from cells exposed to normoxia (control) in
Fig. 7. Abundance of phosphorylated NKCC (p-NKCC) in CMEC following exposures to hypoxia and AVP. For every Western blot conducted to determine NKCC abundance using the T4 antibody (Fig. 7), a parallel Western blot was also conducted to evaluate p-NKCC abundance using R5 antibody, as described in MATERIALS AND METHODS. A: representative Western blot of p-NKCC abundance in CMEC exposed to $19 \%$ $\mathrm{O}_{2}$ for $30 \mathrm{~min}$ or to $7.5 \% \mathrm{O}_{2}$ for 30,90 , or 180 min. $B$ : summary of hypoxia effects on NKCC phosphorylation. ImageQuant software was used to quantitate p-NKCC abundance in Western blots. Values shown are means \pm SE of 7,6 , 7 , and 7 experiments for control $\left(19 \% \mathrm{O}_{2}\right)$ and 30,90 , and $180 \mathrm{~min}$ of $7.5 \% \mathrm{O}_{2}$, respectively. $* P<0.05$, significantly different from control by Student's paired $t$-tests. $C$ : representative Western blot of p-NKCC abundance in CMEC after a 10-min exposure to 0 or $100 \mathrm{nM}$ AVP (-AVP and +AVP, respectively).
A
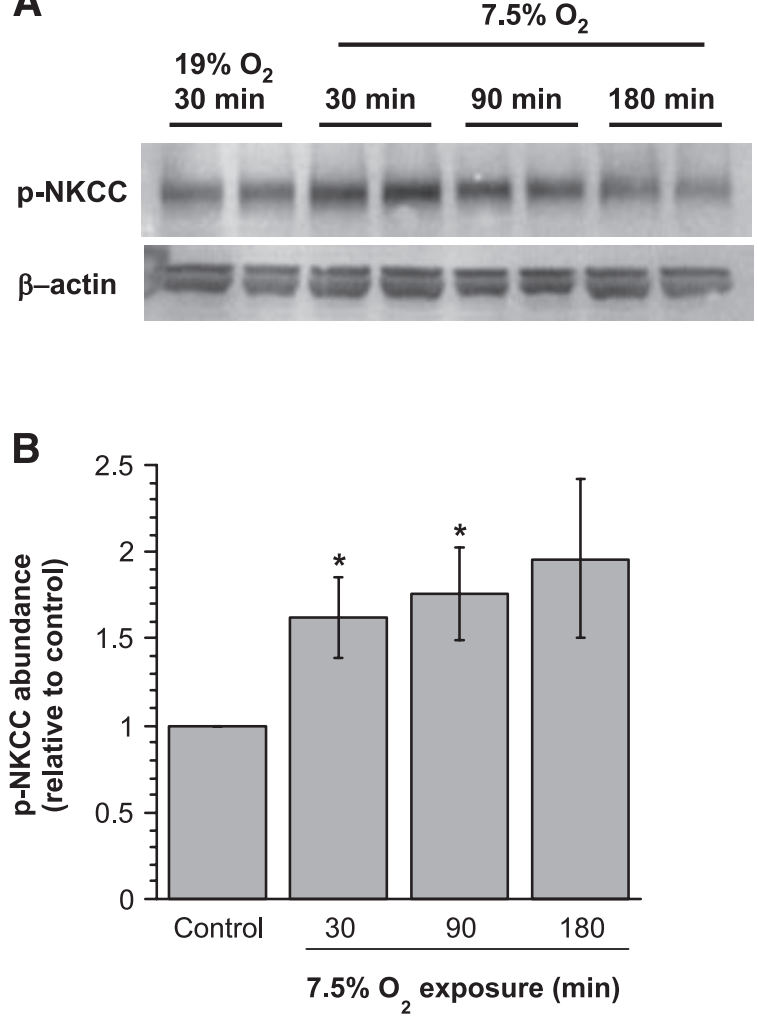

C

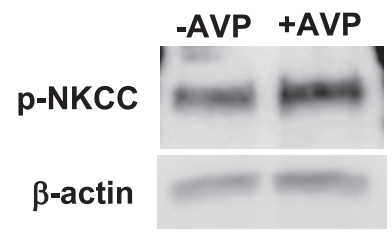


these experiments. Finally, because AVP is increased during cerebral ischemia and stimulates CMEC cotransporter activity, we also tested whether AVP increases p-NKCC abundance. For this, we exposed CMECs to media containing 0 or $100 \mathrm{nM}$ AVP for 10 min under normoxic conditions. In the representative Western blot shown in Fig. 7C, we found that AVP, like hypoxia, caused an increase in CMEC p-NKCC abundance. In six experiments, AVP induced a modest but significant $1.21 \pm$ 0.08 -fold increase in $\mathrm{p}-\mathrm{NKCC}$ over the control (means $\pm \mathrm{SE}$, $P<0.05$ by Student's paired $t$-test). Thus, hypoxia and AVP, two factors present during cerebral ischemia and known to be associated with edema formation, both stimulate $\mathrm{CMEC} \mathrm{Na}^{+}$$\mathrm{K}^{+}-\mathrm{Cl}^{-}$cotransporter activity and also increase phosphorylation of the cotransporter protein.

\section{DISCUSSION}

Hypoxia is a prominent factor present during the early stages of cerebral ischemia when edema rapidly forms across an intact BBB. Our previous studies suggest that the $\mathrm{BBB} \mathrm{Na}{ }^{+}-\mathrm{K}^{+}-\mathrm{Cl}^{-}$ cotransporter is a major participant in ischemia-induced edema formation. The results of the present study demonstrate that hypoxia stimulates activity of the cerebral microvascular endothelial cell $\mathrm{Na}^{+}-\mathrm{K}^{+}-\mathrm{Cl}^{-}$cotransporter within $30 \mathrm{~min}$ and that this occurs over a range of hypoxia levels from moderate to severe. Our studies also show that the levels of hypoxia that stimulate activity of the CMEC cotransporter neither decrease cell ATP content or $\mathrm{Na}^{+}-\mathrm{K}^{+}$-ATPase activity nor cause an increase in CMEC cell volume within the first $3 \mathrm{~h}$ of hypoxia exposure. Finally, we provide evidence herein that hypoxia stimulation of $\mathrm{CMEC} \mathrm{Na}{ }^{+}-\mathrm{K}^{+}-\mathrm{Cl}^{-}$cotransporter activity is associated with an increase in phosphorylation of the cotransporter protein.

The results of our present studies reveal that the CMEC cotransporter is stimulated by hypoxia within $30 \mathrm{~min}$ of exposure to a broad range of $\mathrm{O}_{2}$ levels from $7.5 \% \mathrm{O}_{2}$ down to $0.5 \%$ $\mathrm{O}_{2}\left(39 \%\right.$ to $3 \%$ of normoxic $\left.\mathrm{O}_{2}\right)$. These levels are representative of $\mathrm{O}_{2}$ content approximated for core and penumbral regions, respectively, of an ischemic focus $(2,28)$, suggesting that during cerebral ischemia, a rapid hypoxia-induced increase in $\mathrm{BBB} \mathrm{Na}{ }^{+}-\mathrm{K}^{+}-\mathrm{Cl}^{-}$cotransporter activity occurs in both core and penumbra. We also found that cotransporter activity remains elevated in the continued presence of hypoxia for longer periods with $7.5 \%$ than with $2 \% \mathrm{O}_{2}$. This is consistent with the observation that greater increases in water and $\mathrm{Na}^{+}$content are found in the periphery compared with the center of focal cerebral ischemia in gerbils subjected to right common carotid artery occlusion (19). In addition, our finding that the CMEC cotransporter is stimulated by relatively brief exposure to hypoxia is consistent with previous studies $(12,33,40)$ demonstrating that deoxygenation rapidly stimulates the erythrocyte $\mathrm{Na}^{+}-\mathrm{K}^{+}-\mathrm{Cl}^{-}$cotransporter. For example, turkey erythrocytes exposed for only $15 \mathrm{~min}$ to $9 \% \mathrm{O}_{2}(47 \%$ of normoxic levels) showed increases in cotransporter activity (33) as did ferret erythrocytes exposed to $10 \mathrm{~min}$ of anoxia (11).

Our studies also show that hypoxia can stimulate CMEC cotransporter activity independently of aglycemia. Cerebral ischemia typically involves a reduction in both $\mathrm{O}_{2}$ and glucose. However, a decrease in $\mathrm{O}_{2}$ alone is sufficient to elevate CMEC cotransporter activity because we observed this effect of hypoxia whether the cells were treated in medium with or without glucose. A rather surprising finding was that simply exposing cells to normoxic medium lacking pyruvate and glucose increased cotransporter activity $\sim 2$.6-fold over that observed in normoxic medium containing pyruvate (with or without glucose), and, similarly, hypoxia-stimulated activity was also 2.6-fold higher than that observed in pyruvate-containing medium. Thus the stimulatory effects of hypoxia and pyruvate removal appear to be additive. This finding is explored further in the context of possible signaling pathways regulating CMEC cotransporter activity at the end of the DISCUSSION.

Previous studies have shown that exposing CMECs to $24 \mathrm{~h}$ of $2 \% \quad \mathrm{O}_{2}$ results in increased $\mathrm{Na}^{+}-\mathrm{K}^{+}-\mathrm{Cl}^{-}$cotransporter activity and that this is associated with $\sim 40 \%$ decreases in cell ATP content and $\mathrm{Na}^{+}-\mathrm{K}^{+}$-ATPase activity (20). In contrast to those observations following a 24-h hypoxic exposure, our present studies demonstrate that hypoxia stimulation of CMEC cotransporter activity occurring in the first minutes and hours after the onset of hypoxia is not associated with a drop in cell ATP content or a fall in $\mathrm{Na}^{+}-\mathrm{K}^{+}$-ATPase activity. This was found to be true whether the cells were exposed to hypoxia alone or to hypoxia/aglycemia and whether the hypoxia level was $7.5 \%$ or $2 \% \mathrm{O}_{2}$. In our studies, only after $24 \mathrm{~h}$ of exposure to $2 \% \mathrm{O}_{2}$ did ATP levels fall, and in that case we observed the same $\sim 40 \%$ reduction in ATP previously reported for rat CMEC (20). Thus hypoxia stimulation of CMEC cotransporter activity does not appear to occur via a mechanism requiring a fall in cellular ATP content. However, oligomycin-induced chemical hypoxia can stimulate cotransporter activity while reducing ATP content in rat CMECs (20) and in bovine CMECs (this study). Thus it appears that hypoxia can stimulate the cotransporter even when ATP is reduced. In addition, our present finding that $\mathrm{Na}^{+}-\mathrm{K}^{+}$-ATPase activity is not decreased by the $\mathrm{O}_{2}$ levels and exposure times found to stimulate the CMEC cotransporter (even $2 \% \mathrm{O}_{2}$ for up to $4 \mathrm{~h}$ ) supports the hypothesis that the luminal $\mathrm{BBB} \mathrm{Na}{ }^{+}-\mathrm{K}^{+}-\mathrm{Cl}^{-}$cotransporter works with the abluminal $\mathrm{Na}^{+}-\mathrm{K}^{+}$-ATPase during cerebral ischemia to secrete $\mathrm{Na}^{+}$and $\mathrm{Cl}^{-}$into the brain. This is further supported by the finding that $\mathrm{Na}^{+}-\mathrm{K}^{+}$-ATPase activity measured in the absence of bumetanide (i.e., with a functioning $\mathrm{Na}^{+}-\mathrm{K}^{+}-\mathrm{Cl}^{-}$cotransporter) is actually stimulated by hypoxia.

The $\mathrm{Na}^{+}-\mathrm{K}^{+}-\mathrm{Cl}^{-}$cotransporter is well known to function in volume regulation in a variety of cells, including endothelial cells (41). In earlier studies (36), we showed that in bovine aortic endothelial cells (BAECs), the cotransporter is stimulated by cell shrinkage to mediate a regulatory volume increase, thus restoring intracellular volume. In addition, exposure of BAECs to AVP, endothelin-1, or bradykinin stimulates cotransporter activity and also increases resting intracellular volume of the cells (36). We have also shown previously that the CMEC cotransporter is stimulated by exposure to hyperosmotic media (38), indicating that the cotransporter very likely contributes to regulation of intracellular volume in CMECs. Thus the possibility must be considered that hypoxiainduced stimulation of the CMEC cotransporter could simply cause the cells to swell rather than to participate in edema formation by secreting $\mathrm{Na}^{+}$and $\mathrm{Cl}^{-}$across the BBB. The results of the present study suggest that this is not the case, because we observed an increase in CMEC intracellular volume only after 4 or more hours of exposure to hypoxia. This further supports a role for the cotransporter in ischemiainduced $\mathrm{BBB} \mathrm{Na}{ }^{+}$and $\mathrm{Cl}^{-}$secretion and edema formation 
occurring during the early hours after stroke before breakdown of the barrier occurs.

Our present studies included an initial investigation of signaling events that may be involved in hypoxia-induced stimulation of $\mathrm{CMEC} \mathrm{Na}^{+}-\mathrm{K}^{+}-\mathrm{Cl}^{-}$cotransporter activity. Stimulation of the cotransporter has been shown to be associated with phosphorylation of the $\mathrm{Na}^{+}-\mathrm{K}^{+}-\mathrm{Cl}^{-}$cotransporter protein (NKCC) in several cell types, including erythrocytes, rat parotid acinar epithelial cells, and shark rectal gland $(11,13,14$, 33 ). We have shown previously that ${ }^{32} \mathrm{P}$ incorporation into NKCC protein of BAECs is increased by factors that stimulate the cotransporter, including AVP, bradykinin, and hyperosmotic media. We have also found increased phosphorylation of NKCC protein in both BAECs and CMECs upon exposure to the phosphatase inhibitors okadaic acid and calyculin A (39, 44). More recently, one of us (Forbush and coworkers) developed an antibody (R5) that recognizes phosphorylated NKCC protein and demonstrated that NKCC phosphorylation mirrors activation of the cotransporter in HEK-293 cells, shark rectal gland, rat parotid gland, and rat colonic epithelium $(13,14)$. Previous studies (14) using the R5 antibody have also demonstrated AVP-induced increases in phosphorylation of the renal thick ascending limb $\mathrm{Na}^{+}-\mathrm{K}^{+}-\mathrm{Cl}^{-}$cotransporter. Our present studies using the R5 antibody have revealed that exposing CMECs to hypoxia increases NKCC phosphorylation and that this occurs with a magnitude and time course similar to the hypoxia-induced increase in cotransporter activity. Our studies also reveal that AVP stimulation of CMEC cotransporter activity is associated with increased NKCC phosphorylation. In the case of AVP, the relative increase in phosphorylation observed was modest compared with the increase in activity. The fact that the R5 antibody was raised against a diphosphopeptide containing $\mathrm{Thr}^{212}$ and $\mathrm{Th}^{217}$ of human NKCC suggests that the CMEC cotransporter is likely phosphorylated on one or both those residues. However, it is possible that phosphorylation could occur on other residues as well. Thus the magnitude of phosphorylation observed with the R5 antibody may not reveal the full extent of CMEC NKCC phosphorylation on exposure to AVP and/or hypoxia. In any case, our findings demonstrate that hypoxia and AVP do indeed cause phosphorylation of the CMEC cotransporter as well as stimulation of cotransporter activity and that the phosphorylation is recognized by the R5 antibody, which targets phosphothreonine in the NKCC protein.

While hypoxia increases phosphorylation of CMEC NKCC protein, exposures of up to $4 \mathrm{~h}$ do not alter the abundance of NKCC. This is in contrast to a previous report (45) that NKCC protein of cerebral cortex was found to increase after $2 \mathrm{~h}$ of ischemia plus 0 to $24 \mathrm{~h}$ of reperfusion. However, that study used spontaneously hypertensive rats and also examined NKCC protein of intact cerebral tissue, thus including multiple cell types. Our studies also show that as with hypoxia, AVP increases phosphorylation of CMEC NKCC protein (this study) but does not increase CMEC NKCC abundance at exposures up to $4 \mathrm{~h}$ (37). These findings suggest that the CMEC cotransporter is stimulated by hypoxia and AVP over a time course consistent with early edema formation during stroke in a manner that does not involve an increase in the amount of NKCC protein.

The present study has not addressed the possible signaling pathways that lead to hypoxia-induced phosphorylation and stimulation of the CMEC cotransporter. However, bovine CMECs exhibit transient increases in intracellular $\mathrm{Ca}^{2+}$ concentration $\left(\left[\mathrm{Ca}^{2+}\right]_{\mathrm{i}}\right)$ within $1 \mathrm{~h}$ of exposure to $1 \% \mathrm{O}_{2}(8)$, and we have shown previously that the CMEC cotransporter is stimulated by elevation of $\left[\mathrm{Ca}^{2+}\right]_{\mathrm{i}}$, suggesting that a rise in $\left[\mathrm{Ca}^{2+}\right]_{\mathrm{i}}$ may participate in hypoxia stimulation of the CMEC cotransporter. In addition, hypoxia stimulation of turkey erythrocyte cotransporter activity can be inhibited by the protein kinase C inhibitor staurosporine (33), and staurosporine reduces bovine $\mathrm{CMEC} \mathrm{Na}^{+}-\mathrm{K}^{+}-\mathrm{Cl}^{-}$cotransporter activity stimulated by $6 \mathrm{~h}$ of combined hypoxia/aglycemia (1). There is also evidence that hypoxia activates the phosphatidylinositol 3-kinase/Akt pathway in porcine CMECs (10). Whether these pathways and/or other kinase pathways are involved in hypoxia stimulation of the CMEC cotransporter remains to be determined.

Our observation that CMEC cotransporter activity was increased more than twofold simply by removing pyruvate and glucose from the assay medium suggests that the cotransporter is highly sensitive to the metabolic status of the cells. In this regard, AMP-activated protein kinase (AMPK) is rapidly emerging as an important sensor of cell metabolic status and has been shown to be activated by hypoglycemia as well as by hypoxia and ischemia $(16,17)$. Even very small decreases in the cell ATP/ADP ratio through adenylate kinase conversion of ADP to AMP cause activation of AMPK, which then acts on a variety of targets $(16,17,25)$. Among these, AMPK appears to modulate cystic fibrosis transmembrane conductance regulator activity in T84 cells, thereby coupling ion transport to cell metabolism, and it has been suggested that AMPK very likely also modulates the activity of other ion transport proteins (15). This suggests the possibility that CMEC cotransporter stimulation by pyruvate removal could occur through activation of AMPK. Furthermore, because AMPK can be activated by hypoxia, it is possible that it may also participate in hypoxia stimulation of CMEC cotransporter activity. Determining the signaling pathways that mediate the effects of hypoxia and metabolic status on the CMEC cotransporter activity requires further study.

In summary, the main findings of the present study, i.e., that the CMEC $\mathrm{Na}^{+}-\mathrm{K}^{+}-\mathrm{Cl}^{-}$cotransporter is sensitive to and rapidly stimulated by modest to severe reductions in $\mathrm{O}_{2}$ without significant changes in $\mathrm{Na}^{+}-\mathrm{K}^{+}$-ATPase activity, cell ATP content, or cell volume, collectively support the hypothesis that during the early hours of stroke, hypoxia stimulation of the cotransporter contributes to cerebral edema formation. In addition, our findings suggest that hypoxia effects on the cotransporter are mediated, at least in part, by phosphorylation of the cotransporter protein.

\section{GRANTS}

This work was supported by an American Heart Association Western States Grant-in-Aid, National Institute of Neurological Disorders and Stroke Grant NS-039953, and an External Research Program Grant from Philip Morris USA and Philip Morris International (all grants to M. E. O'Donnell).

\section{REFERENCES}

1. Abbruscato TJ, Lopez SP, Roder K, and Paulson JR. Regulation of blood-brain barrier $\mathrm{Na}, \mathrm{K}, 2 \mathrm{Cl}$-cotransporter through phosphorylation during in vitro stroke conditions and nicotine exposure. J Pharmacol Exp Ther 310: 459-468, 2004.

2. Baringa M. Finding new drugs to treat stroke. Science 272: 646-666, 1996. 
3. Bender AS, Schousboe A, Reichelt W, and Norenberg MD. Ionic mechanisms in glutamate-induced astrocyte swelling: role of $\mathrm{K}^{+}$influx. J Neurosci Res 52: 307-321, 1998.

4. Betz AL. Sodium transport from blood to brain: inhibition by furosemide and amiloride. J Neurochem 41: 1158-1164, 1983.

5. Betz AL. Sodium transport in capillaries isolated from rat brain. $J \mathrm{Neu}$ rochem 41: 1150-1157, 1983.

6. Betz AL, Keep RF, Beer ME, and Ren X. Blood-brain barrier permeability and brain concentration of sodium, potassium, and chloride during focal ischemia. J Cereb Blood Flow Metab 14: 29-37, 1994.

7. Bourke RS, Kimelberg HK, Nelson LR, Barron KD, Auen EL, Popp AJ, and Waldman JB. Biology of glial swelling in experimental brain edema. Adv Neurol 28: 99-109, 1980

8. Brown RC, Mark KS, Egleton RD, and Davis TP. Protection against hypoxia-induced blood-brain barrier disruption: changes in intracellular calcium. Am J Physiol Cell Physiol 286: C1045-C1052, 2004.

9. Cserr HF, DePasquale M, Patlak CS, and Pullen RGL. Convection of cerebral interstitial fluid and its role in brain volume regulation. Ann NY Acad Sci 481: 123-134, 1989.

10. Fischer S, Wiesnet M, Marti HH, Renz D, and Schaper W. Simultaneous activation of several second messengers in hypoxia-induced hyperpermeability of brain derived endothelial cells. J Cell Physiol 198: 359369, 2004.

11. Flatman PW. Activation of ferret erythrocyte $\mathrm{Na}^{+}-\mathrm{K}^{+}-2 \mathrm{Cl}^{-}$cotransport by deoxygenation. J Physiol 563: 421-431, 2005.

12. Flatman PW. Deoxygenation stimulates $\mathrm{Na}^{+}-\mathrm{K}^{+}-2 \mathrm{Cl}^{-}$cotransport in ferret erythrocytes. J Physiol 531: 122P-123P, 2001.

13. Flemmer AW, Giménez I, Dowd BFX, Darman RB, and Forbush B. Activation of the Na-K-Cl cotransporter NKCC1 detected with a phosphospecific antibody. J Biol Chem 277: 37551-37558, 2002.

14. Giménez I and Forbush B. Short-term stimulation of the renal Na-K-Cl cotransporter (NKCC2) by vasopressin involves phosphorylation and membrane translocation of the protein. J Biol Chem 278: 26946-26951, 2003.

15. Hallows KR, Kobinger GP, Wilson JM, Witters LA, and Foskett JK. Physiological modulation of CFTR activity by AMP-activated protein kinase in polarized T84 cells. Am J Physiol Cell Physiol 284: C1297C1308, 2003.

16. Hardie DG. The AMP-activated protein kinase pathway-new players upstream and downstream. J Cell Sci 117: 5479-5487, 2004.

17. Hardie DG. Minireview: the AMP-activated protein kinase cascade: the key sensor of cellular energy status. Endocrinology 144: 5179-5183, 2003.

18. Iadecola C. Mechanisms of cerebral ischemic damage. In: Cerebral Ischemia: Molecular and Cellular Pathophysiology, edited by Walz W. Totowa, NJ: Humana, 1999, p. 3-34.

19. Kato H, Kogure K, Sakamoto N, and Watanabe T. Greater disturbance of water and ion homeostasis in the periphery of experimental focal cerebral ischemia. Exp Neurol 96: 118-126, 1987.

20. Kawai N, McCarron RM, and Spatz M. Effect of hypoxia on $\mathrm{Na}^{+}-\mathrm{K}^{+}$ $\mathrm{Cl}^{-}$cotransport in cultured brain capillary endothelial cells of the rat J Neurochem 66: 2572-2579, 1996.

21. Kawai N, McCarron RM, and Spatz M. $\mathrm{Na}^{+}-\mathrm{K}^{+}-\mathrm{Cl}^{-}$cotransport system in brain capillary endothelial cells: response to endothelin and hypoxia. Neurochem Res 21: 1259-1266, 1996.

22. Keep RF. Potassium transport at the blood-brain and blood-CSF barriers. In: Frontiers in Cerebral Vascular Biology: Transport and Its Regulation, edited by Drewes LR and Betz AL. New York: Plenum, 1993, p. 43-54.

23. Kimelberg HK. Cell swelling in cerebral ischemia. In: Cerebral Ischemia: Molecular and Cellular Pathophysiology, edited by Walz W. Totowa, NJ: Humana, 1999, p. 45-68.

24. Kimelberg HK. Current concepts of brain edema. Review of laboratory investigations. J Neurosurg 83: 1051-1059, 1995.

25. Kishi K, Yuasa T, Minami A, Yamada M, Hagi A, Hayashi H, Kemp BE, Witters LA, and Ebina Y. AMP-activated protein kinase is activated by the stimulations of $\mathrm{G}_{\mathrm{q}}$-coupled receptors. Biochem Biophys Res Commun 276: 16-22, 2000
26. Kletzien RF, Pariza MW, Becker JE, and Potter VR. A method using 3-O-methyl-D-glucose and phloretin for the determination of intracellular water space of cells in monolayer culture. Anal Biochem 68: 537-544, 1975.

27. Latzkovits L, Cserr HF, Park JT, Patlak CS, Pettigrew KD, and Rimanoczy A. Effects of arginine vasopressin and atriopeptin on glial cell volume measured as 2-MG space. Am J Physiol Cell Physiol 264: C603-C608, 1993.

28. Liu S, Timmins GS, Shi H, Gasparovic CM, and Liu KJ. Application of in vivo EPR in brain research: monitoring tissue oxygenation, blood flow, and oxidative stress. NMR Biomed 17: 327-334, 2004.

29. Lytle C, Xu JC, Biemesderfer D, and Forbush B III. Distribution and diversity of $\mathrm{Na}-\mathrm{K}-\mathrm{Cl}$ cotransport proteins: a study with monoclonal antibodies. Am J Physiol Cell Physiol 269: C1496-C1505, 1995.

30. Meloni BP, Majda BT, and Knuckey NW. Establishment of neuronal in vitro models of ischemia in 96-well microtiter strip plates that result in acute, progressive and delayed neuronal death. Neuroscience 108: 17-26, 2001.

31. Menzies SA, Betz AL, and Hoff JT. Contributions of ions and albumin to the formation and resolution of ischemic brain edema. J Neurosurg 78: 257-266, 1993.

32. Munns SE and Arthur PG. Stability of oxygen deprivation in glass culture vessels facilitates fast reproducible cell death to cortical neurons under simulated ischemia. Anal Biochem 306: 149-152, 2002.

33. Muzyamba MC, Cossins AR, and Gibson JS. Regulation of $\mathrm{Na}^{+}-\mathrm{K}^{+}-$ $2 \mathrm{Cl}^{-}$cotransport in turkey red cells: the role of oxygen tension and protein phosphorylation. J Physiol 517: 421-429, 1999.

34. O'Donnell M, Tran L, Lam TI, Liu XB, and Anderson SE. Bumetanide inhibition of the blood-brain barrier $\mathrm{Na}-\mathrm{K}-\mathrm{Cl}$ cotransporter reduces edema formation in the rat middle cerebral artery occlusion model of stroke. J Cereb Blood Flow Metab 24: 1046-1056, 2004.

35. O'Donnell ME. Regulation of Na-K-Cl cotransport in endothelial cells by atrial natriuretic factor. Am J Physiol Cell Physiol 257: C36-C44, 1989.

36. O'Donnell ME. Role of Na-K-Cl cotransport in vascular endothelial cell volume regulation. Am J Physiol Cell Physiol 264: C1316-C1326, 1993.

37. O'Donnell ME, Duong V, Suvatne J, Foroutan S, and Johnson DM. Arginine vasopressin stimulation of cerebral microvascular endothelial cell Na-K-Cl cotransporter activity is $\mathrm{V}_{1}$ receptor and $[\mathrm{Ca}]$ dependent. Am J Physiol Cell Physiol 289: C283-C292, 2005.

38. O'Donnell ME, Martinez A, and Sun D. Cerebral microvascular endothelial cell $\mathrm{Na}-\mathrm{K}-\mathrm{Cl}$ cotransport: regulation by astrocyte-conditioned medium. Am J Physiol Cell Physiol 268: C747-C754, 1995.

39. O'Donnell ME, Martinez A, and Sun D. Endothelial Na-K-Cl cotransport regulation by tonicity and hormones: phosphorylation of cotransport protein. Am J Physiol Cell Physiol 269: C1513-C1523, 1995.

40. Palfrey HC and Greengard P. Hormone-sensitive ion transport systems in erythrocytes as models for epithelial ion pathways. Ann Proc NY Acad Sci 372: 291-309, 1981

41. Palfrey HC and O'Donnell ME. Characteristics and regulation of the Na/K/2Cl cotransporter. Cell Physiol Biochem 2: 293-307, 1992.

42. Schielke GP, Moises HC, and Betz AL. Blood to brain sodium transport and interstitial fluid potassium concentration during focal ischemia in the rat. J Cereb Blood Flow Metab 11: 466-471, 1991.

43. Sun D, Lytle C, and O'Donnell ME. Astroglial cell-induced expression of Na-K-Cl cotransporter in brain microvascular endothelial cells. Am J Physiol Cell Physiol 269: C1506-C1512, 1995.

44. Sun D and O'Donnell ME. Astroglial-mediated phosphorylation of $\mathrm{Na}-\mathrm{K}-\mathrm{Cl}$ cotransporter in brain microvessel endothelial cells. Am J Physiol Cell Physiol 271: C620-C627, 1996.

45. Yan Y, Dempsey RJ, Flemmer A, Forbush B, and Sun D. Inhibition of $\mathrm{Na}-\mathrm{K}-\mathrm{Cl}$ cotransporter during focal cerebral ischemia decreases edema and neuronal damage. Brain Res 961: 22-31, 2003.

46. Yerby TR, Vibat CRT, Sun D, Payne JA, and O'Donnell ME. Molecular characterization of the Na-K-Cl cotransporter of bovine aortic endothelial cells. Am J Physiol Cell Physiol 273: C188-C197, 1997. 